\title{
Does our Education System Allow Students to Be Autonomous?
}

\author{
Ĕ̆itim Sistemimiz Ö̆̆rencilerin Özerk Olmasına İzin Veriyor mu?
}

\section{F. Özlem SAKA*}

\begin{abstract}
Learner autonomy is one of the most important concepts supported by the Constructivist Approach and the Common European Framework of Reference for Languages. Learner autonomy means that a learner plans, monitors his/her learning, recognizes his/her weak points, takes measures to overcome them and evaluates his/her improvement. To be able to do this, learners should be supported by the educational system, teachers and parents. When our educational system is examined, it can be seen it is based upon exams. Students can get the chance of good education upon the condition that they obtain high grades, both in the school exams and in the national exams given at two different levels. School principals, teachers and parents all expect students to be successful in these exams. Can students be autonomous in these circumstances? Does the system in Turkey support learner autonomy? To answer these questions, $8^{\text {th }}$ grade students from 4 different schools in Antalya were given a questionnaire and their ideas on this subject were collected. The results were analysed with SPSS and suggestions are made to remove the identified obstacles to enable students to be autonomous.
\end{abstract}

Keywords: Learner Autonomy, Exams in English Language Teaching, Common European Framework of Reference for Languages

Öz: Öğrenci özerkliği özellikle de Avrupa Dilleri Öğretimi Ortak Çerçeve Programı ve Yapılandırmacı Yaklaşım ile eğitim hayatımıza girmiş bir kavramdır. Öğrenci Özerkliği kavramı öğrencinin kendi öğrenimini planlamasını, gelişimini izlemesini, eksiklerini belirlemesini, bu eksikleri giderici çalışmalar yapmasını ve kendini değerlendirmesini içermektedir. Öğrencinin bunu başarabilmesi için eğitim sisteminin buna imkan sağlaması, öğretmenlerin ve anne-babaların da bunu desteklemesi gereklidir. Eğitim sistemimizde öğrenci başarısı sınav odaklı olarak değerlendirilmektedir ve yüksek puanlar almak başarılı olmanın ön şartıdır. Bu durumda öğrenci özerkliğinden söz edilebilir mi? İlköğretim 8. sınıfa gelmiş öğrenciler özerk öğrenci niteliği taşımakta mıdır? Bu sorulara yanıt bulmak amacıyla Antalya İli’nde 4 farklı ortaokulun 8. sınıf öğrencilerine bir anket uygulanarak bu konudaki görüşleri alınmıştır. SPSS'te analiz edilen sonuçlara göre durum değerlendirmesi yapılmış ve özerk öğrenci yetiştirmek için öneriler ortaya konulmuştur.

Anahtar sözcükler: Öğrenci Özerkliği, Yabancı Dil Öğretiminde Sınavlar, Avrupa Dilleri Öğretimi Ortak Çerçeve Programı

\section{Introduction}

In the $21^{\text {st }}$ century, educational problems are still being discussed in this country and attempts to find ways to improve the quality and the effectiveness of education are made. One of the problems in education, which has remained unsolved for years, concerns foreign language

\footnotetext{
*Assist. Prof. Dr., Akdeniz University, Faculty of Education, Foreign Languages Teaching Department, Antalya, ozlemsaka@akdeniz.edu.tr
} 
teaching. We have spread foreign language teaching programmes from primary school to university level, increased the hours of foreign language classes and changed our books according to the modern approaches. However, the situation of students learning foreign languages has not reached our expectations. We cannot make them read, write, speak, listen and understand in a foreign language, in other words, we cannot make them use a foreign language fluently. There can be many reasons for this problem; it can be a consequence of the educational system, of teacher training, of teachers, books, methods or of the students themselves. Influenced by this problem, students should certainly participate in all research on this matter. The main objective of education is to teach students to improve their educational level over the course of their lives (Özden, 1997, 20). Therefore, the extent to which they develop their learning skills has been investigated, as well as the reasons why they are unsuccessful.

When we examine the approaches to modern foreign language teaching, we find the Common European Framework of References for Languages (CEFR). CEFR is a framework for curriculum, books and examinations all over Europe, with the aim of guiding language learners as to what to learn, what language skill to improve upon in order to use a foreign language to communicate effectively (Council of Europe, 2001, 1). As well as creating a standard criterion for foreign language teaching in Europe, in terms of teaching and assessing, it presents the concepts of plurilingualism and learner autonomy (Demirel, 2005). The European Language Portfolio (ELP) requires students to plan, to monitor and to evaluate their learning. Providing the students with guidance and assessment criteria, ELP aims to support students in developing their learning strategies, enabling them to become autonomous learners (Lenz, 2004, 23).

The educational approach which has recently become widely known in our country is the constructivist approach. Educational programs have been designed according with the principles of the constructivist approach, books have been written and teachers have been given inservice training to learn constructivist classroom applications. According to the constructivist approach, learners begin the learning process with their own sets of knowledge and experiences and with the help of this repertoire they try to understand the world and its situations (Williams, 1999, 12). Constructivism gives learners an active role (Perkins, 1999, 8). Gray (1997) states knowledge is constructed by the student through the process of active cognitive development rather than from the teacher. Constructivism emphasizes learning, not teaching and supports learner autonomy and the student's effective involvement in learning (Wang, 2011, 274).

Both the CEFR and the Constructivist Approach focus upon learner autonomy and learning to learn. Consequently the concept, learner autonomy, needs to be clarified. Holec (cited in Lili, 2008) defines learner autonomy as the skill of being responsible for his/her learning. Little thinks (http://archive.ecml.at/mtp2/Elp_tt/Results/DM_layout/0010/06/06\%20Supplementary \%2text.pdf), autonomous learners are students motivated by learning and these students can also use what they have learnt outside of school efficiently. Learner autonomy is the individualisation of learning (Gardner, 2000, 51). Autonomous learners move forward through being conscious of the importance of their attempts (Scharle, \& Szabo, 2000, 3). One of the disadvantages of traditional methods is that they do not give a chance to the learners to enable their own learning process; the other disadvantage is that they do not permit the students to discover their own learning strategies (Müller-Verwegen, 1999, 79-80). Autonomous learners determine their objectives based upon the curriculum, choose the relevant materials and activities to improve their learning and to evaluate the output of learning (Dam, \& Legenhausen, 1999, 91). In this respect, autonomous learners are independent of their teachers and do not wait to do what needs to be done (Scharle, \& Szabo, 2000, 4). Little $(1999,13)$ emphasizes the 
importance of the learner taking the responsibility for his/her learning through pointing out that the autonomy of many successful scientists and researchers' does not result from their educational background.

On the other hand, the education system in Turkey is based upon examinations. Testing and the evaluation of a students' improvement forms an indispensible part of the educational system. However, the grades the students obtain in their examinations during the term are termed, school success grade and are added to the national exam result. The combination of these two grades in certain ratios, determines which school the student should attend the following year. Secondary school grades are important for high school exams, high school grades for university exams. Therefore, the grades are of great importance to both students and their parents as these determine the future education of the students and, to some considerable extent, their future prospects. Many parents feel more anxious about these results than their own children and the behaviour they exhibit sometimes affects the children so badly that it can cause them to suffer from depression (Yildırım, 2006, 190). Furthermore, in their educational process students concentrate on the topics that will be asked in the exams, rather than trying to understand the topics and develop their own learning skills. These national exams are composed of multiple choice questions, and this form of examination requires students to remember individual points instead of presenting what they know in a considered and coherent form. In foreign language teaching, improving language skills is important. As the form of these examinations is multiple choice questions, students, under the pressure of this imperative, tend to look to find easy ways to solve the questions, this instead of producing examples of their language skills especially in speaking and writing. The fact that most ELT students who have obtained high grades in English in university entrance exams, fail in speaking, listening and in written examinations is the clear and evident proof of this. In some schools, where students' success and parental expectation for a better education is high, teachers stop following the curriculum in the exam year and design a new program based upon exam questions, and teach accordingly. From this perspective, examinations, a means of determining the improvement in students learning, instead becomes the primary aim of the educational system.

In our educational system in which there is, on the one hand the contemporary foreign language teaching approaches, and, on the other, there is this opposite application. It is necessary to evaluate the attitudes of both parents and reflections of students in respect to examinations.

\subsection{Problem of the Study}

How can any educational system which is based to such an extent upon exams be evaluated in terms of learner autonomy?

\subsection{Purpose of the Study}

It is of the utmost important to reflect how students interpret the problem observed in educational institutions. In this study the attempt is made to obtain answers to the following questions from the students' ideas:

1. What is the ratio of students who believe getting higher grades in exams is important?

2. What is the ratio of students who believe the grades they get from the exams show that they have learnt the subjects?

3. What is the ratio of students who think his/her parents give importance to his/her grades?

4. What is the ratio of students who believe the high grades they get from these exams 
prove that they have learnt the subjects?

5. What is the ratio of students who give importance to learning rather than get high grades?

6. What is the ratio of students who consult their teachers concerning the subjects they haven't learnt?

7. What is the ratio of students who attempt to learn the topics they haven't understood?

8. What is the ratio of parents who think that the students' learning is more important than their grades?

9. What is the ratio of students who do not give a good performance in the exams even if they know the topic?

10. What is the ratio of students who believe that their anxiety about getting low grades in the examination prevents their learning?

11. What is the ratio of students who know what they know and what they do not know?

12. What is the ratio of students who would like to compensate for their failure?

13. What is the ratio of students who think the grades they get from the exams reflect what they know or they do not know?

14. What is the ratio of students who think that those students getting high grades in the exams are the successful students?

15. What is the ratio of students who think low grades do not show that they do not know?

\subsection{Importance of the Study}

This study is important because through combining the behaviour which refers to learner autonomy and students' perceptions related to exams, it attempts to show if learner autonomy is possible within our educational system.

\subsection{Limitations}

This study is limited to $8^{\text {th }}$ grade students from 4 secondary schools in Antalya and is further limited to the ideas of those students who participated in this research.

\section{Method}

This study is a descriptive study employing the survey method which shows the present situation in the educational system from the ideas of $8^{\text {th }}$ grade students.

In this study, 4 secondary schools which were convenient were chosen to join the research. A questionnaire was prepared by the researcher, checked by experts in the field and was given to $8^{\text {th }}$ grade students. To obtain reliable results, $8^{\text {th }}$ grade students who are old enough to make a better evaluation were preferred. The number of students who participated in this research was 513.

The questionnaire was prepared to determine the ideas of students concerning exams and exam results and was controlled by experts in the field. The questionnaire was composed of the 15 questions given above, and 3 different possible answers: "yes", "sometimes" and "no". Students were expected to choose the answer that best reflects his/her idea concerning the question asked.

\section{Results}

Students were given the questionnaire and the data were collected. This data was examined through the SPSS and the results of this study are presented in detail in this part.

Students were asked if obtaining higher grades in the exams is important for them, their answers are shown as in Table 1 . Female students with the ratio of $84.8 \%$ and male students with $81.4 \%$ answered this question positively, only $3.3 \%$ of the students said no to this question. 
As can be seen, there is statistically no significant difference between female and male students $\left(\chi^{2}=2.522 ; \mathrm{P}>.05\right)$.

Table 1. Students who believe getting higher grades is important

\begin{tabular}{|l|c|c|c|c|c|c|c|c|}
\hline Question 1 & \multicolumn{9}{|c|}{ Always } & \multicolumn{2}{|c|}{ Sometimes } & \multicolumn{2}{c|}{ Never } & \multicolumn{2}{c|}{ Total } \\
\hline & $\mathrm{N}$ & $\%$ & $\mathrm{~N}$ & $\%$ & $\mathrm{~N}$ & $\%$ & $\mathrm{~N}$ & $\%$ \\
\hline Female & 207 & 84.8 & 32 & 13.1 & 5 & 2.0 & 244 & 100.0 \\
\hline Male & 219 & 81.4 & 38 & 14.1 & 12 & 4.5 & 269 & 100.0 \\
\hline Total & 42.6 & 83.0 & 70 & 13.6 & 17 & 3.3 & 513 & 100.0 \\
\hline
\end{tabular}

$\chi^{2}=2.522 \quad \mathrm{df}=2 \quad \mathrm{P}=.283$

There is no statistically significant difference between two genders on this question $\left(\chi^{2}=.526\right.$; $\mathrm{P}>.05$ ). Students were asked if the exam results accurately reflect their performance concerning what they have learnt, $57.7 \%$ of the students answered this question with a 'yes', $33.1 \%$ with 'sometimes' and $9.2 \%$ did not believe that the exams accurately reflect their performance.

Table 2. Students who think exam results accurately reflect their performance

\begin{tabular}{|l|c|c|c|c|c|c|c|c|}
\hline \multirow{2}{*}{ Question 2 } & \multicolumn{9}{|c|}{ Sometimes } & \multicolumn{2}{c|}{ No } & \multicolumn{2}{c|}{ Total } \\
\hline & $\mathrm{N}$ & $\%$ & $\mathrm{~N}$ & $\%$ & $\mathrm{~N}$ & $\%$ & $\mathrm{~N}$ & $\%$ \\
\hline Female & 144 & 59.0 & 77 & 31.6 & 23 & 9.4 & 244 & 100.0 \\
\hline Male & 152 & 56.5 & 93 & 34.6 & 24 & 8.9 & 269 & 100.0 \\
\hline Total & 296 & 57.7 & 170 & 33.1 & 47 & 9.2 & 513 & 100.0 \\
\hline
\end{tabular}

$\chi^{2}=.526 \quad \mathrm{df}=2 \quad \mathrm{P}=.769$

When asked if their parents give importance to their exam results, they replied as follows: 73.9 $\%$ of the students said their grades are important to their parents. The ratio of students who said that their parents did not care about their exam results was quite low, a ratio of $7.8 \%$. There was no statistically significant difference in terms of gender on this question $\left(\chi^{2}=1.487 ; \mathrm{P}>.05\right)$.

Table 3. Students who think their parents give importance to their Exam results

\begin{tabular}{|l|c|c|c|c|c|c|c|c|}
\hline Question 3 & \multicolumn{9}{|c|}{ Yes } & \multicolumn{2}{c|}{ Sometimes } & \multicolumn{2}{c|}{ No } & \multicolumn{2}{c|}{ Total } \\
\hline & \multicolumn{2}{|c|}{ Yes } & $\mathrm{N}$ & $\%$ & $\mathrm{~N}$ & $\%$ & $\mathrm{~N}$ & $\%$ \\
\hline Female & 175 & 71.7 & 50 & 20.5 & 19 & 7.8 & 244 & 100.0 \\
\hline Male & 204 & 75.8 & 44 & 16.4 & 21 & 7.8 & 269 & 100.0 \\
\hline Total & 379 & 73.9 & 94 & 18.3 & 40 & 7.8 & 513 & 100.0 \\
\hline
\end{tabular}

$$
\chi^{2}=1.487 \quad \mathrm{df}=2 \quad \mathrm{P}=.475
$$

Table 4 shows the ratio of the students who believe that high grades in the exams reflect how well they know the subjects. In total, half the students believe that getting higher grades means knowing the subject well. The ratio for the answer 'sometimes' was $38.8 \%$. The ratio of students who answered the question negatively was only $8.6 \%$. Employing the Chi- Square test $(\chi 2=1.060 ; \mathrm{P}>.05)$ no statistically significant difference in terms of gender was found. 
Table 4. Students who believe they show their learning by obtaining higher grades

\begin{tabular}{|c|c|c|c|c|c|c|c|c|}
\hline \multicolumn{9}{|c|}{ Question 4} \\
\hline & \multicolumn{2}{|c|}{ Yes } & \multicolumn{2}{|c|}{ Sometimes } & \multicolumn{2}{|c|}{ No } & \multicolumn{2}{|c|}{ Total } \\
\hline & $\mathrm{N}$ & $\%$ & $\mathrm{~N}$ & $\%$ & $\mathrm{~N}$ & $\%$ & $\mathrm{~N}$ & $\%$ \\
\hline Female & 133 & 54.5 & 89 & 36.5 & 22 & 9.0 & 244 & 100.0 \\
\hline Male & 137 & 50.9 & 110 & 40.9 & 22 & 8.2 & 269 & 100.0 \\
\hline Total & 270 & 52.6 & 199 & 38.8 & 44 & 8.6 & 513 & 100.0 \\
\hline
\end{tabular}

$$
\chi^{2}=1.060 \quad \mathrm{df}=2 \quad \mathrm{P}=.589
$$

The ratio of students who believe learning is more important than the exam grades is shown in Table 5 . For $33.7 \%$ of the students learning was more important than exam grades. The ratio of students who answer the question as 'sometimes' was $40.0 \%$. Believing the opposite, $26.3 \%$ of students said learning was not more important than exam grades. There is no statistically significant difference between the two genders for this question $\left(\chi^{2}=.925 ; \mathrm{P}>.05\right)$.

Table 5. Students who believe learning is more important than the grades

\begin{tabular}{|c|c|c|c|c|c|c|c|c|}
\hline \multicolumn{9}{|l|}{ Question 5} \\
\hline & \multicolumn{2}{|c|}{ Yes } & \multicolumn{2}{|c|}{ Sometimes } & \multicolumn{2}{|c|}{ No } & \multicolumn{2}{|c|}{ Total } \\
\hline & $\mathrm{N}$ & $\%$ & $\mathrm{~N}$ & $\%$ & $\mathrm{~N}$ & $\%$ & $\mathrm{~N}$ & $\%$ \\
\hline Female & 80 & 32.8 & 95 & 38.9 & 69 & 28.3 & 244 & 100.0 \\
\hline Male & 93 & 34.6 & 110 & 40.9 & 66 & 24.5 & 269 & 100.0 \\
\hline Total & 173 & 33.7 & 205 & 40.0 & 135 & 26.3 & 513 & 100.0 \\
\hline
\end{tabular}

$$
\chi^{2}=.925 \quad \mathrm{df}=2 \quad \mathrm{P}=.630
$$

Students were asked if they consulted their teacher when they did not understand a point and their answers form Table 6. 40\% of participants answered this question positively, $46.8 \%$ said 'sometimes' and only $13.3 \%$ replied in the negative. The Chi-Square test $\left(\chi^{2}=17.934 ; \mathrm{P}<.01\right)$ showed a statistically significant difference between female and male students in terms of consulting the teacher when they needed to. Half of the female students said 'yes' and only 9.4 $\%$ of them said 'no'. Whereas a ratio of $31.6 \%$ male students said 'yes'; while the ratio of male students who said 'no'was also higher than those of the female students.

\begin{tabular}{|c|c|c|c|c|c|c|c|c|}
\hline \multicolumn{9}{|c|}{ Question 6} \\
\hline & \multicolumn{2}{|c|}{ Yes } & \multicolumn{2}{|c|}{ Sometimes } & \multicolumn{2}{|c|}{ No } & \multicolumn{2}{|c|}{ Total } \\
\hline & $\mathrm{N}$ & $\%$ & $\mathrm{~N}$ & $\%$ & $\mathrm{~N}$ & $\%$ & $\mathrm{~N}$ & $\%$ \\
\hline Female & 120 & 49.2 & 101 & 41.4 & 23 & 9.4 & 244 & 100.0 \\
\hline Male & 85 & 31.6 & 139 & 51.7 & 45 & 16.7 & 269 & 100.0 \\
\hline Total & 205 & 40.0 & 240 & 46.8 & 68 & 13.3 & 513 & 100.0 \\
\hline
\end{tabular}

Table 6. The ratio of students who consult the teacher when needed

$$
\chi^{2}=17.934 \quad \mathrm{df}=2 \quad \mathrm{P}=.000
$$


Students were asked if they made efforts to learn a topic when they did not understand it. Their answers are shown in Table 7. The ratio of students who made efforts to learn a topic is $59.3 \%$. The ratio of the female students (65.5\%) is higher than that of the male students (59.3\%). The ratio of students who made no effort to learn was $7.2 \%$. This question produced a statistically significant difference between female and male students $\left(\chi^{2}=17.934 ; \mathrm{P}<.01\right)$. Female students seem more willing to learn the points they do not understand than the male students with the answer 'Yes'. On the other hand, more male students accepted that they sometimes try to learn.

Table 7. Students who make the effort to learn when they don't understand

\begin{tabular}{|l|c|c|c|c|c|c|c|c|}
\hline Question 7 & \multicolumn{9}{|c|}{} & \multicolumn{2}{c|}{ Sometimes } & \multicolumn{2}{c|}{ No } & \multicolumn{2}{c|}{ Total } \\
\hline & \multicolumn{2}{|c|}{ Yes } & $\mathrm{N}$ & $\%$ & $\mathrm{~N}$ & $\%$ & $\mathrm{~N}$ & $\%$ \\
\hline Female & 160 & 65.6 & 73 & 29.9 & 11 & 4.5 & 244 & 100.0 \\
\hline Male & 144 & 53.5 & 99 & 36.8 & 26 & 9.7 & 269 & 100.0 \\
\hline Total & 304 & 59.3 & 172 & 33.5 & 37 & 7.2 & 513 & 100.0 \\
\hline
\end{tabular}

$\chi^{2}=17.934 \quad \mathrm{df}=2 \quad \mathrm{P}=.008$

The ratio of students who believe their parents find their learning more important than their grades is shown in Table 8. For the half of the all students, their parents pay more attention to their learning rather than their grades. When the same question was examined in terms of gender, the ratio for the female students is $55.7 \%$, while for the male students it is $45.4 \%$. There is a statistically significant difference between the two genders on this question $\left(\chi^{2}=6.726 ; \mathrm{P}<.05\right)$.

Table 8. Students who think their learning is for their parents more important than their obtaining high grades

\begin{tabular}{|c|c|c|c|c|c|c|c|c|}
\hline \multicolumn{9}{|c|}{ Question 8} \\
\hline & \multicolumn{2}{|c|}{ Yes } & \multicolumn{2}{|c|}{ Sometimes } & \multicolumn{2}{|c|}{ No } & \multicolumn{2}{|c|}{ Total } \\
\hline & $\mathrm{N}$ & $\%$ & $\mathrm{~N}$ & $\%$ & $\mathrm{~N}$ & $\%$ & $\mathrm{~N}$ & $\%$ \\
\hline Female & 136 & 55.7 & 72 & 29.5 & 36 & 14.8 & 244 & 100.0 \\
\hline Male & 122 & 45.4 & 88 & 32.7 & 59 & 21.9 & 269 & 100.0 \\
\hline Total & 258 & 50.3 & 160 & 31.2 & 95 & 18.5 & 513 & 100.0 \\
\hline
\end{tabular}

$$
\chi^{2}=6.726 \quad \mathrm{df}=2 \quad \mathrm{P}=.035
$$

The students were asked if examinations provided an accurate picture of their performance, the following table gives their replies. The ratio of the students who said even they if they knew the subject, they could not deliver their accurate performance was $28.1 \%$. The ratio of the students who said 'no' to the question is $19.9 \%$. While half the students answered 'sometimes', which is quite interesting. This indicates examinations cause problems for students from time to time. From the Chi-Square test $\left(\chi^{2}=.619 ; \mathrm{P}>.05\right)$ no statistically significant difference between genders was found. 
Table 9. Students who are not successful in the exams even if they know the subject

\begin{tabular}{|c|c|c|c|c|c|c|c|c|}
\hline \multicolumn{9}{|c|}{ Question 9} \\
\hline & \multicolumn{2}{|c|}{ Yes } & \multicolumn{2}{|c|}{ Sometimes } & \multicolumn{2}{|c|}{ No } & \multicolumn{2}{|c|}{ Total } \\
\hline & $\mathrm{N}$ & $\%$ & $\mathrm{~N}$ & $\%$ & $\mathrm{~N}$ & $\%$ & $\mathrm{~N}$ & $\%$ \\
\hline Female & 68 & 27.9 & 124 & 50.8 & 52 & 21.3 & 244 & 100.0 \\
\hline Male & 76 & 28.3 & 143 & 53.2 & 50 & 18.6 & 269 & 100.0 \\
\hline Total & 144 & 28.1 & 267 & 52.0 & 102 & 19.9 & 513 & 100.0 \\
\hline
\end{tabular}

$$
\chi^{2}=.619 \quad \mathrm{df}=2 \quad \mathrm{P}=.734
$$

The students were asked if test anxiety prevents them from learning, they gave answers recorded in Table 10. The ratio of the students who said 'yes' and 'no' for the question is similar but the ratio of the students who answered the question as 'sometimes' is higher, a ratio of $42.3 \%$. It is worrying to obtain such a high ratio for this answer. From the Chi-Square test there was no statistically significant difference between genders $\left(\chi^{2}=.226\right.$; $\left.P>05\right)$.

Table 10. Students recording test anxiety prevented them from learning

\begin{tabular}{|c|c|c|c|c|c|c|c|c|}
\hline \multicolumn{9}{|l|}{ Question 10} \\
\hline & \multicolumn{2}{|c|}{ Yes } & \multicolumn{2}{|c|}{ Sometimes } & \multicolumn{2}{|c|}{ No } & \multicolumn{2}{|c|}{ Total } \\
\hline & $\mathrm{N}$ & $\%$ & $\mathrm{~N}$ & $\%$ & $\mathrm{~N}$ & $\%$ & $\mathrm{~N}$ & $\%$ \\
\hline Female & 71 & 29.1 & 104 & 42.6 & 69 & 28.3 & 244 & 100.0 \\
\hline Male & 75 & 27.9 & 113 & 42.0 & 81 & 30.1 & 269 & 100.0 \\
\hline Total & 146 & 28.5 & 217 & 42.3 & 150 & 29.2 & 513 & 100.0 \\
\hline
\end{tabular}

$$
\chi^{2}=.226 \quad \mathrm{df}=2 \quad \mathrm{P}=.894
$$

The answers to the question 'Do you follow your learning?' are as follows. Nearly half the students said they followed their learning. The second group, almost as large, are the students who said 'sometimes' with a ratio of $43.5 \%$. It is a hopeful sign that the ratio of the students who replied 'no' to this question was only $10.7 \%$. From the Chi-Square test no statistically significant difference was found between genders $\left(\chi^{2}=2.909 ; \mathrm{P}>.05\right)$.

Table 11. Students who monitor their learning

\begin{tabular}{|l|c|c|c|c|c|c|c|c|}
\hline Question 11 & \multicolumn{9}{|c|}{ Yos } & \multicolumn{2}{|c|}{ Sometimes } & \multicolumn{2}{c|}{ No } & \multicolumn{2}{c|}{ Total } \\
\hline & \multicolumn{2}{|c|}{ Yes } & $\mathrm{N}$ & $\%$ & $\mathrm{~N}$ & $\%$ & $\mathrm{~N}$ & $\%$ \\
\hline Female & 119 & 48.8 & 104 & 42.6 & 21 & 8.6 & 244 & 100.0 \\
\hline Male & 116 & 43.1 & 119 & 44.2 & 34 & 12.6 & 269 & 100.0 \\
\hline Total & 235 & 45.8 & 223 & 43.5 & 55 & 10.7 & 513 & 100.0 \\
\hline
\end{tabular}

$$
\chi^{2}=2.909 \quad \mathrm{df}=2 \quad \mathrm{P}=.234
$$

The ratio of the students who try to improve their learning is shown in the table below. Those replying 'yes' with a ratio of $59.8 \%$ and, 'sometimes' with a ratio of $33.3 \%$, indicate most students thought they attempted to improve themselves. From the Chi-Square test there is a statistically significant difference between the female and male students in terms of this 
question $\left(\chi^{2}=13.406 ; \mathrm{P}<.01\right)$. The ratio of female students who replied 'yes' to the question $(68.0 \%)$ is higher than for the male students $(52.4 \%)$. The ratio for the answer 'sometimes' from the female students $(25.8 \%)$ is lower than from the male students $(40.1 \%)$. The ratio of the answer 'no' is $6.1 \%$ for the female students and $7.4 \%$ for the male students.

Table 12. Students who try to improve their learning

\begin{tabular}{|l|c|c|c|c|c|c|c|c|}
\hline \multirow{2}{*}{ Question 12 } & \multicolumn{9}{|c|}{ Yos } & \multicolumn{2}{c|}{ Sometimes } & \multicolumn{2}{c|}{ No } & \multicolumn{2}{c|}{ Total } \\
\hline & $\mathrm{N}$ & $\%$ & $\mathrm{~N}$ & $\%$ & $\mathrm{~N}$ & $\%$ & $\mathrm{~N}$ & $\%$ \\
\hline Female & 166 & 68.0 & 63 & 25.8 & 15 & 6.1 & 244 & 100.0 \\
\hline Male & 141 & 52.4 & 108 & 40.1 & 20 & 7.4 & 269 & 100.0 \\
\hline Total & 307 & 59.8 & 171 & 33.3 & 35 & 6.8 & 513 & 100.0 \\
\hline$\chi^{2}=13.406$ & $\mathrm{df}=2$ & $\mathrm{P}=.001$ & & & & & & \\
\hline
\end{tabular}

The students were asked how much the exam results reflected what they already know, their replies are in Table 13, with $48.1 \%$ of the students replying 'yes' and $40.0 \%$ replying 'sometimes' results that show most of the students believe the exam results show how much they know. From the Chi-Square test no statistically significant difference was found between genders $\left(\chi^{2}=1.001 ; \mathrm{P}>.05\right)$.

Table 13. Students who think the exam results reflect what they know

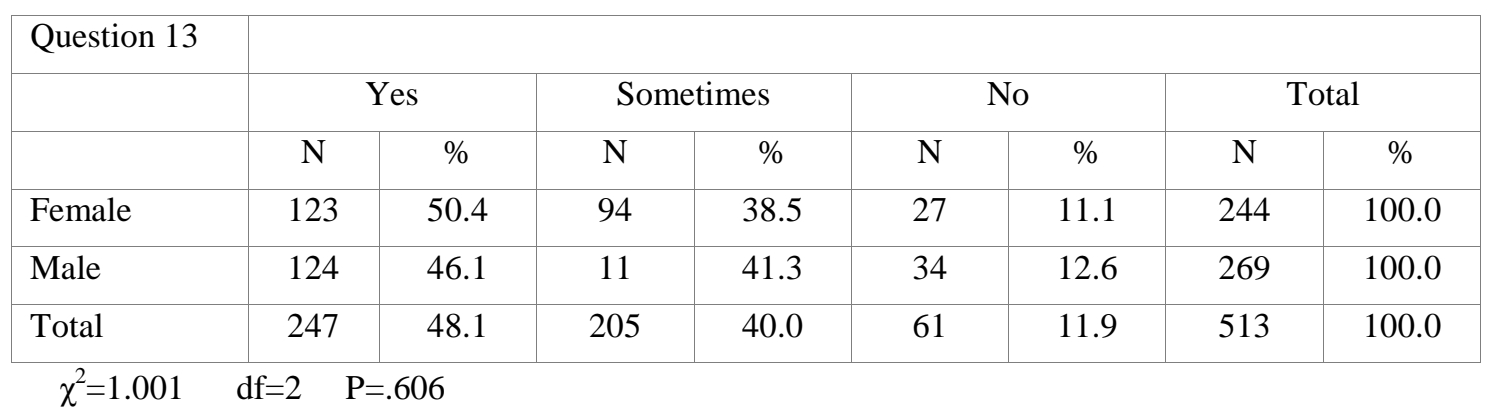

The ratio of students who believe that those students with good grades from the exams are the successful students is given in the following table. The ratio for 'yes' is $36.3 \%$, for 'sometimes' $32.0 \%$ and for 'no' $31.8 \%$. This shows that students did not think the high-grade result students were always the successful students. From the Chi-Square test no statistically significant difference was found between genders $\left(\chi^{2}=1.577 ; \mathrm{P}>.05\right)$.

Table 14. Students thinking those students with high grades are the successful students

\begin{tabular}{|c|c|c|c|c|c|c|c|c|}
\hline \multicolumn{9}{|c|}{ Question 14} \\
\hline & \multicolumn{2}{|c|}{ Yes } & \multicolumn{2}{|c|}{ Sometimes } & \multicolumn{2}{|c|}{ No } & \multicolumn{2}{|c|}{ Total } \\
\hline & $\mathrm{N}$ & $\%$ & $\mathrm{~N}$ & $\%$ & $\mathrm{~N}$ & $\%$ & $\mathrm{~N}$ & $\%$ \\
\hline Female & 91 & 37.3 & 82 & 33.6 & 71 & 29.1 & 244 & 100.0 \\
\hline Male & 95 & 35.3 & 82 & 30.5 & 92 & 34.2 & 269 & 100.0 \\
\hline Total & 186 & 36.3 & 164 & 32.0 & 163 & 31.8 & 513 & 100.0 \\
\hline
\end{tabular}


The students were asked if obtaining low grades indicated they did not know the subject, their replies given in Table 15. Answering 'yes' with a ratio of 53.8\% and 'sometimes' with a ratio of $31.2 \%$, the students' state they can know the topic, even if they obtain lower grades. The ratio of the students who replied 'no' to this question was $15.0 \%$. From the Chi-Square test no statistically significant difference was found between genders $\left(\chi^{2}=.763 ; \mathrm{P}>.05\right)$.

Table 15. Students thinking that obtaining lower grades does not show they don't know

\begin{tabular}{|c|c|c|c|c|c|c|c|c|}
\hline \multicolumn{9}{|l|}{ Question 15} \\
\hline & \multicolumn{2}{|c|}{ Yes } & \multicolumn{2}{|c|}{ Sometimes } & \multicolumn{2}{|c|}{ No } & \multicolumn{2}{|c|}{ Total } \\
\hline & $\mathrm{N}$ & $\%$ & $\mathrm{~N}$ & $\%$ & $\mathrm{~N}$ & $\%$ & $\mathrm{~N}$ & $\%$ \\
\hline Female & 130 & 53.3 & 80 & 32.8 & 34 & 13.9 & 244 & 100.0 \\
\hline Male & 146 & 54.3 & 80 & 29.7 & 43 & 16.0 & 269 & 100.0 \\
\hline Total & 276 & 53.8 & 160 & 31.2 & 77 & 15.0 & 513 & 100.0 \\
\hline
\end{tabular}

$\chi^{2}=.763 \quad \mathrm{df}=2 \quad \mathrm{P}=.683$

\section{Discussion and Suggestions}

When the data was examined and interpreted, it is evident that students pay close attention to their examination results, particularly those students who would like to sit the national examination to attend a qualified high school or to gain a place at university. The higher the school grade is, the larger the contribution it makes to the national examination, meaning the student will obtain a higher grade.

While some students believe that their examination results at school record their learning level, others trust the results only occasionally. The reason for this could be the difference between the evaluation criteria employed by teachers and those of the students. If the students do not know what subjects were to be tested in the exam, in what way and how their responses were to be evaluated, they cannot succeed. As a result of this, they can lose their trust in exams.

Hoping that their children achieve higher grades, parents pay too much attention to their offsprings' examination results. The difference between the genders shows that in particular female students feel this attention as being a kind of parental pressure loaded on them. Yavuzer (2005, 37) explains that young people complain about their parents for being oppressive, having high expectations of them and interfering in their lives. Further, to make learners autonomous, they should be free from the control of others (Benson, 2011'2,14). With the traditional behaviour of parents, it does not seem to be possible to develop the capacity in learners to take control of their own learning.

Although students do not always think that their exam results reflect what they learn, they consider that the results showing high grades prove their learning. For them, high grades are the sign of success and therefore obtaining these high grades is important. However, they also record that learning is more important than getting high grades.

When the students do not understand anything in the lessons, some of them prefer to ask the teacher for help. Theose students who always consult the teacher when they have a problem with the lesson are mainly female students. The statistically significant difference between them shows that in this respect the genders behave differently. This difference could result from the different kind of behaviour exhibited by both genders in terms of their interactions. As Maccoby (cited in Morris, 1993, 380) points out, afraid of losing face, male students tend to keep silence whereas females are less competitive and more willing to reveal themselves. 
Students say that they make efforts when they do not understand a point. They believe for their parents, their learning is more important than their obtaining high grades. On the other hand, they also state that with the expectation of higher grades from their children, their parents cause them to feel anxiety for the examinations. Text anxiety is another factor that affects students' success. The students also believe that in some examinations, they are not successful even if they know the subject. This means that there are problems with the examination in terms of its content-validity. As school exams should contain the subjects taught at school, students are expected to know them and to obtain good grades. Some students think that exams give information about what they know and some others believe that they do not have the chance to get feedback from some of the exams. This is a drawback for the students to become autonomous, as the teachers' feedback is of the utmost important after the examinations for learner autonomy.

Students record that they follow their progress and they try to improve their language. They indicate that those students who obtain the high grades are not necessarily the successful students. They also state that those students receiving low grades, does not mean that those students do not know the subjects.

It is therefore evident that our students cannot take control of their learning due to the pressure exerted by the educational system in Turkey. From an early age, they know that they should study hard to be successful in examinations to obtain a good place in the future. However, they don't care how much they learn if only they obtain good grades.They try to improve their testing abilities to overcome difficulties in the examinations employing the help of private teachers.

The following suggestions can be made to change this situation:

1. Teachers should be informed and trained in methods enabling their students to become autonomous.

2. Teachers should be given seminers about test preparation and sharing with teachers the complaints of students concerning the examinations, the effectiveness of the exams should be improved.

3. Language programs and examinations should be designed in a manner that will give a chance to teach learner autonomy and learning to learn.

4. Teachers should work collaboratively with parents in order to make the students autonomous learners.

5. Students should use ELP and from time to time, should evaluate themselves through the self-assessment grid for their own age group, under the supervision of the teacher and their parents. 


\section{REFERENCES}

Benson, P. (2011). Teaching and Researching Autonomy. Harlow: Pearson Education.

Council of Europe (2001). Common European Framework of Reference for Languages: Learning, Teaching, Assessment. Cambridge: Cambridge University Press.

Dam, L., \& Legenhausen, L. (1999). "Language Acquisition in an Autonomous learning Environment: Learners' Self-evaluations and External Assessments Compared”. Eds.: S. Cotterall, \& D. Crabbe. Learner Autonomy: In Language Learning: Defining the Field and Effecting Change, 8, 89-98. Frankfurt am Main: Peter Lang.

Demirel, Ö. (2005). “Avrupa Konseyi Dil Projesi ve Türkiye Uygulaması”. Milli Eğitim, 33/167. T.C. Millî Eğitim Bakanlığı Yayımlar Dairesi Başkanlığı.

Gardner, D. (2000). "Self-Assessment for Autonomous Language Learners”. Links \& Letters. 7, 49-60.

Gray, A. (1997). "Constructivist Teaching and Learning STTA Research Centre Report”. From http:// www.saskschoolboards.ca/old/ResearchAndDevelopment/ResearchReports/Instruction/9707.htm http://archive.ecml.at/mtp2/Elp_tt/Results/DM_layout/00_10/06/06\%20Supplementary\%20text.pdf

Lenz, P. (2004). “The European Language Portfolio”. Insights From the Common European Framework, 22-31. Oxford: Oxford University Press.

Li-li, Wu. (2008). “On Cultivation of Learner Autonomy in EFL Classroom”. US-China Foreign Language, 6/3, 43-46. March 2008.

Little, D. (1999). "Learner Autonomy is more than a Western Cultural Construct". Eds.: S. Cotterall, \& D. Crabbe. Learner Autonomy: In Language Learning: Defining the Field and Effecting Change, 1118. Frankfurt am Main: Peter Lang.

Morris, C. G. (1993). Psychology. New Jersey: A Simon \& Schuster Company.

Müller-Verwegen, M. (1999). "Reflections as a Means of Acquiring Autonomy”. Eds.: S. Cotterall, \& D. Crabbe. Learner Autonomy: In Language Learning: Defining the Field and Effecting Change, 79-88 Frankfurt am Main: Peter Lang.

Özden, Y. (1997). Öğrenme ve Öğretme. Pegem: Ankara.

Perkins, D. (1999). “The Many Faces of Constructivism”. Educational Leadership. 6-11. November , 57/3.

Wang, P. (2011) . "Constructivism and Learner Autonomy in Foreign Language Teaching and Learning: To What Extent Does Theory Inform Practice?”. Theory and Practice in Language Studies, 273- 277. March 2011, 1/3.

Williams, M. (1999). "Learning Teaching: A Social Constructivist Approach-Theory and Practice or Theory with Practice?”. Eds. H. Trapez-Lomaz, \& I. McGrath. Theory in Language Teacher Education, 11-20. Essex: Pearson Education Limited.

Yavuzer, H. (2005). Gençleri Anlamak. İstanbul: Remzi Kitabevi.

Yıldırım, İ. (2006). Anne Baba Desteği ve Başarı. Ankara: Anı Yayıncılık. 